\title{
Uz temu
}

U znanstvenom diskursu europskih, pa tako i hrvatskih, demografa, sociologa, makroekonomista i znanstvenika s drugih srodnih znanstvenih područja, od 1980-ih godina sve je prisutnija problematika niskoga fertiliteta. Širina interesa i istraživačka interdisciplinarnost, sama po sebi, upućuje na opću društvenu važnost ovoga fenomena. Prvotno kao posljedica dugogodišnjega snižavanja fertiliteta, a potom i produženja očekivanoga trajanja života, velika većina europskih zemalja suočena je s intenzivnim procesom demografskoga starenja, tj. s porastom broja i udjela stanovništva starog 65 i više godina $i$, suprotno tomu, padom priljeva mladih na tržište radne snage. S početkom ulaska u mirovinu brojnijih naraštaja obuhvaćenih državnim mirovinskim sustavom pojavila se $i$ kriza sustava, jer je sve nepovoljniji brojčani odnos između aktivnih osiguranika i umirovljenika. K tomu, uz mirovinski sustav, demografsko starenje nepovoljno utječe na ekonomski rast, štednju, investicije, potrošnju, tržište rada i porezne sustave. Pod pritiskom općih gospodarskih $i$ društvenih razvojnih procesa uslijedile su i promjene odnosa unutar obitelji. Zapošljavanje žena izvan kućanstva unijelo je posve nove činitelje u sferu fertiliteta. U kojoj će mjeri žena u suvremenim uvjetima moći spojiti ulogu majke i zaposlene žene ovisi o poduzetim institucionalnim mjerama. Pozornost plijeni poznata činjenica prema kojoj od 12 najrazvijenijih europskih zemalja njih devet ima i najviši fertilitet. Te zemlje imaju i najviše stope zaposlenosti ženskoga stanovništva u fertilnoj dobi. Pri tome treba imati na umu činjenicu da u njima veći broj žena radi s nepunim radnim vremenom, bez obzira na to što imaju najrazvijenije javne politike koje olakšavaju teret zaposlenosti $i$ skrb o djeci. Svaka zemlja, pa tako i Hrvatska, ima svoje posebnosti ograničene konkretnim gospodarskim i društvenim prilikama koje utječu na fertilitetnu motivaciju. Tijekom svojega dvadesetogodišnjeg izlaženja časopis Društvena istraživanja objavio je, osim niza pojedinačnih radova, više tematskih brojeva o raznim aspektima demografske problematike u Hrvatskoj. Nastavljajuci tu praksu, ovaj broj Društvenih istraživanja objavljuje dio istraživačkih rezultata nastalih u okviru projekta "Povezanost fertiliteta i sektora zaposlenosti žena u Hrvatskoj". Istraživanje se provodilo na poticaj i uz podršku Ministarstva obitelji, branitelja i međugeneracijske solidarnosti od veljače do travnja 2007. godine terenskim anketiranjem na reprezentationom proporcionalnom kvotnom uzorku zaposlenih žena na svim područjima (županijama) Hrvatske. Anketiranjem je obuhvaćeno 1309 zaposlenih žena u Hrvatskoj u dobi od 20 do 39 godina, neovisno o bračnom stanju i imanju/neimanju djece. Istraživački rezultati koje ovdje objavljujemo upućuju na neke kritične segmente u pogledu fertilitetne motivacije zaposlenih žena u Hrvatskoj, što je analizirano na razini sektora u kojem su zaposlene.

Od pet radova koji su sastavni dijelovi ovoga tematskog bloka, tri su nastala u okviru spomenutoga projekta, i to: "Sektor zaposlenosti žena i fertilitet u Hrvatskoj", "Obrazovanje i fertilitet zaposlenih žena u Hrvatskoj" $i$ "Usklađivanje poslovnoga i obiteljskoga života u Hrvatskoj: utjecaj na fertilitet". Radovi: "Sociodemografske odrednice zaposlenosti žena u Hrvatskoj" $i$ "Hrvatska u postindustrijsko doba - Promjene u strukturi radno aktivnoga stanovništva po sektorima djelatnosti $i$ spolu" nisu nastali u okviru spomenutoga projekta. Njima se produbljuje analiza strukturnih promjena u zaposlenosti žena na mikrorazini $i$, općenito, zaposlenosti na makrorazini u Hrvatskoj. Stoga su 
nužan $i$ sastavni dio cjelokupne tematizirane problematike koji pridonosi boljem razumijevanju fertilitetne motivacije. Konačno, radovi obuhvaćeni ovim brojem Društvenih istraživanja svojevrstan su nastavak dosadašnjih empirijskih istraživanja više istraživača o raznim činiteljima fertilitetne motivacije u Hrvatskoj. Vjerujemo da smo, barem dijelom, pridonijeli osvjetljavanju ove zaista složene suvremene problematike.

Andelko Akrap 